\begin{tabular}{|c|l|}
\hline Title & $\begin{array}{l}\text { Minimum A rea Required for Local Popul ations of Japanese Macaques Estimated from the Relationship Between } \\
\text { Habitat A rea and Population Extinction }\end{array}$ \\
\hline Author(s) & Agetsuma, Naoki \\
\hline Citation & $\begin{array}{l}\text { International Journal of Primatology, 28(1), 97-106 } \\
\text { https://doi.org/10.1007/310764-006-9101-9 }\end{array}$ \\
\hline Issue Date & 2007-02 \\
\hline Doc URL & http://hdl.handle.net/2115/47079 \\
\hline Rights & The original publication is available at www.springerlink.com \\
\hline Type & article (author version) \\
\hline File Information & ijp2007.pdf \\
\hline
\end{tabular}

Instructions for use 


\title{
Minimum Area Required for Local Populations of Japanese Macaques Estimated from the Relationship Between Habitat Area and Population Extinction
}

\author{
Naoki Agetsuma 1,2 \\ 1Field Science Center for Northern Biosphere, Hokkaido University, Tomakomai Experimental Forest, Takaoka, Tomakomai 053-0035, Japan. \\ 2To whom correspondence should be addressed; e-mail: agetsuma@ fsc.hokudai.ac.jp. \\ Received March 2, 2005; revision August 23, 2005; accepted January 25, 2006
}

I estimated the minimum area required (MAR) for local populations of Japanese macaques (Macaca fuscata) from empirical data on habitat area and population viability. I used logistic regression analysis to examine the relationship between habitat area and survival/extinction among 50 populations over 50 yr. Estimated habitat areas satisfying 95-99\% probability of a population persisting for 100-1000 yr range from 525 to $975 \mathrm{~km}^{2}$. However, confidence limits of parameters in the logistic regression equation are very large. Moreover, the number of extinct population might be underestimated in the empirical data. Consequently, a much wider habitat area $\left(>1000 \mathrm{~km}^{2}\right)$ should be considered for actual conservation planning for local populations of Japanese macaques. The method involves fewer variables and assumptions than previous methods of MAR estimation, and therefore may be a more useful way to estimate MAR for various species and regions.

KEYWORDS: habitat area; Japanese macaque; logistic regression; minimum area required; population viability analysis.

\section{INTRODUCTION}

Population viability analysis (PVA) is an important tool for wildlife conservation planning. Key measures are the minimum viable population (MVP) and the minimum area required (MAR; Shaffer, 1981). More individuals than the MVP and a greater habitat area than the MAR must be maintained for local populations to have a high survival probability. In general, MVP and MAR are estimated based on a $95 \%$ or $99 \%$ probability of a population surviving for 100 or $1000 \mathrm{yr}$ (Primack, 1995; Shaffer, 1981). Researchers have estimated MVP for a variety of species, including some primates (Berger, 1990; Kinnaird and O'Brien, 1991; Sæther et al., 1998). Some authors have also used mathematical modeling (Lande, 1987; Wissel and Zaschke, 1994). In contrast, studies of MAR are limited (Armbruster and Lande, 1993; Thiollay, 1989). Nevertheless, MAR is the more practical measure for conservation planning. Maintenance of a sufficient habitat area is a critical requirement for wildlife conservation because the major cause of species extinction is habitat destruction (Reid and Miller, 1989). In addition, habitat area measures, such as area of occupancy and extent of occurrence (IUCN, 2001), are generally much easier to obtain than measures of a population size with various demographic parameters.

Researchers have usually calculated MAR from MVP combined with many estimates and assumptions regarding species ecology. Calculation of MVP requires some estimates and assumptions: the survival and reproduction rate of individuals of each sex and age, environmental stochasticity (Armbruster and Lande 1993; Sæther et al., 1998), effective population size (Kinnaird and O'Brien, 1991), dispersion ability, and metapopulation structures (Lande, 1987). 
Moreover, one should also define the distribution type of each estimate and independence among estimates (Sæther et al., 1998). Calculation of MAR also requires other estimates and assumptions, such as population density (Armbruster and Lande, 1993; Thiollay, 1989), home range size (Allen et al., 2001; Thiollay, 1989), social system, habitat condition, and distribution (Lande, 1987; McKelvey et al., 1993).

A weakness of the approach is that it is based on many estimates and assumptions. Moreover, estimating the data requires the accumulation of myriad intensive studies of the species' ecology. However, one can estimate MAR directly without the need to estimate MVP if data are available for extinction/survival of populations in habitat areas of different size and without the need to incorporate a variety of ecological considerations. I estimated MAR for Japanese macaques (Macaca fuscata) directly from empirical data on the habitat area and local population viability.

\section{METHODS}

\section{Materials}

Japanese macaques are endemic to Japan, inhabiting a variety of forest types from warm to the cool temperate zones (Takasaki, 1981). From 1941 to the mid-1970s (excluding 1945-1950), intensive logging of natural forests and widespread establishment of single-species conifer plantations greatly disturbed their habitat (Agetsuma, 1999a), causing fragmentation of the population. Though gradual recovery occurred in some areas, the macaques began to damage crops seriously (Oi et al., 1997; The Southern Kanto Organization for the Study and Information of Japanese Macaques, 1995) and were killed as pests. Local governments conducted pest control intensively around 1980, killing 5000-10,000 macaques each year since 1990 (Agetsuma, 1999a). The attempts at pest control have had little effect on reducing crop raiding (Agetsuma, 1998, 1999a), but they may have had a serious impact on the conservation status of Japanese macaques. The IUCN listed the Japanese macaque as an endangered species (EN) in 1996 and changed the classification to data deficient (DD) in 2000. Because the main cause of the great increase in crop raiding could be habitat destruction, protection of remaining habitats and improvement of their quality are necessary for both the prevention of crop raiding and conservation of Japanese macaques (Agetsuma, 1995, 1998, 1999b).

Japanese macaques form groups consisting of matrilineally kin-related females and immigrant adult males. The groups have relatively fixed ranging areas and reside continuously in many regions; neighboring group ranges overlap with one another to some extent. Males migrate from their natal groups after sexual maturity (about 5-6 yr old) and immigrate into other mixed-sex groups. The typical dispersal distance of adult males from one group to another is $\leqq 11 \mathrm{~km}(n=4$; Koganezawa, 1995; $n=$ 1; Muroyama et al., 2000; $n=2$; Agetsuma, unpublished data). However, habitat areas of Japanese macaques are defined as mixed-sex group locations because males cannot remain in 1 location unless they find mixedsex

groups. Contrarily, female transfer or dispersal is rare (Sugiura et al., 2002). Even when group fissions occur, fissioned groups tend to stay nearby and share the original ranges to some extent (Maruhashi, 1982). Genetic studies of local populations of macaques have shown that some populations $\leqq 20 \mathrm{~km}$ of each other have different types of mitochondrial DNA (Kawamoto, 2002).

Koganezawa (1995) tried to estimate local populations of Japanese macaques from group location information. He analyzed locations of groups surveyed in 1923 (Amagasa and Ito, 1978) and in 1978 (data from Japan Environment Agency) throughout Japan. The source of the information was mainly questionnaires from local people who were closely related with wildlife and forests. Reliability of the information might have improved by 1978, because researchers repeated similar questionnaire surveys in 1953 (Iwano, 1974), 1964 (Uehara and Koganezawa, 1976), and 1978 (Honyurui Bunpu Chousa Kaken Group, 1979), and questionnaire protocols were more systematic and sophisticated than in the 
original survey. The Japan Environment Agency obtained data in 1978 consulting results of Honyurui Bunpu Chousa Kaken Group (1979). Koganezawa (1995) plotted locations of observed macaque groups into approximately $5 \times 5 \mathrm{~km}$ grid squares on 1:50,000 scale maps published by the Geographical Survey Institute of Japan. I assumed that habitats where macaque groups were found $\leqq$ $15 \mathrm{~km}$ of one another were of the same local population, whereas those isolated by $>15 \mathrm{~km}$ or isolated by natural barriers from others were of different local populations, which more or less reflects the usual male dispersal length and spatial divergence of mitochondrial DNA. In this way, Koganezawa (1995) extracted 50 population occupying $25-19,675 \mathrm{~km}^{2}$ of habitat area (areas of occupancy [IUCN, 2001]; unit of area of $25 \mathrm{~km}^{2}$ ) in 1923 . I similarly analyzed data for 1978 and concluded that 16 of the 50 populations reported in 1923 were extinct by 1978.

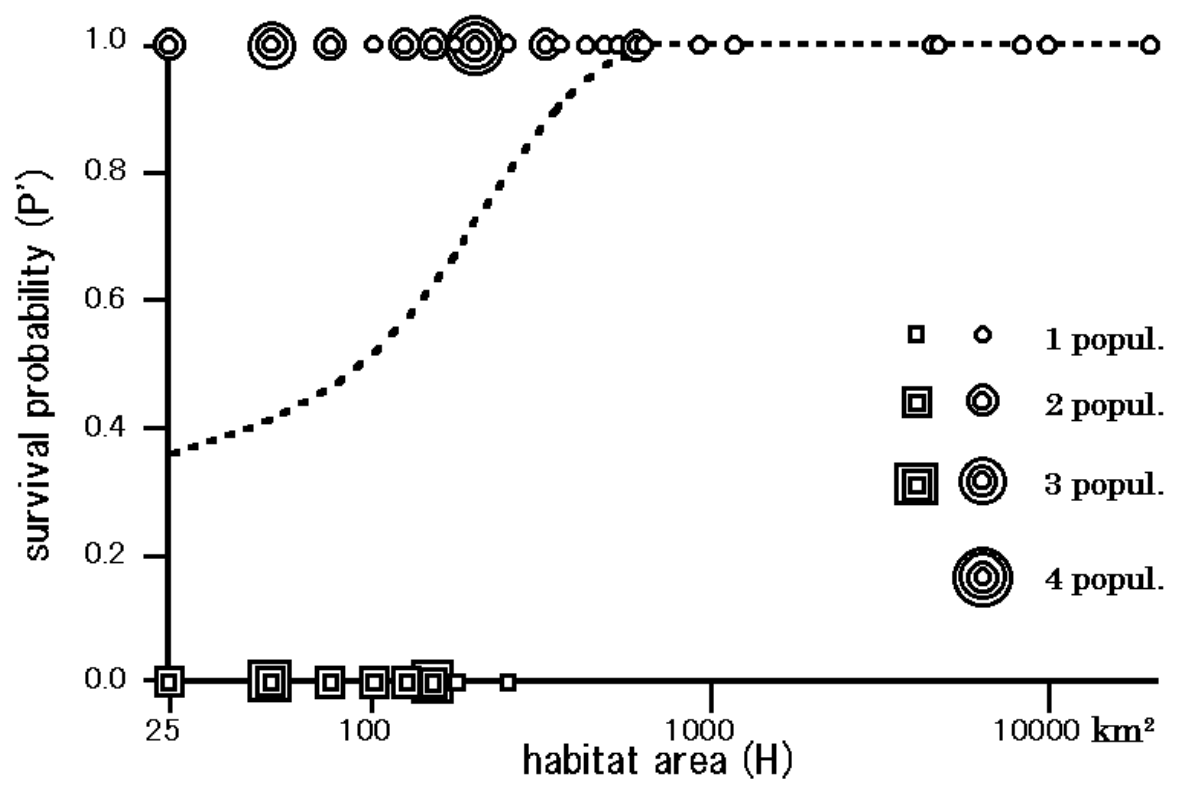

Fig. 1. Relationship between habitat area $(H)$ and survival and extinction of 50 local populations of Japanese macaques between 1923 and 1978. Surviving populations (circles) are in $y=1$ and extinct populations (squares) are in $y=0$. The broken line shows the logistic regression line, indicating survival probability $\left(P_{-}\right)$in relation to habitat area over $55 \mathrm{yr}$. I transformed the $x$-axis into a logarithmic scale.

\section{Analysis}

I used empirical data on habitat areas and viability of the 50 local populations of Japanese macaques from 1923 to 1978 (Koganezawa, 1995) for MAR estimation. The number of extinct populations is likely to be an underestimate. Recolonization of areas where local populations became extinct might have occurred within $55 \mathrm{yr}$. Moreover, populations that recolonized might become extinct again in $\leqq$ $55 \mathrm{yr}$. I assumed that recolonization between the 2 survey periods did not occur.

The relationship between habitat area (areas of occupancy in $25 \mathrm{~km}^{2}$ unit) and survival or extinction 
of 50 populations of Japanese macaques from 1923 to 1978 (Koganezawa, 1995) is in Fig. 1. I obtained the relevant regression equation from a logistic model (Dobson, 1990) via Stat View, ver. 5.0 (SAS Institute, 1998), expressed as

$P_{-}=e(C+A \times H) /(1+e(C+A \times H))$,

where $P_{-}$represents the probability of survival for a population with habitat area $H\left(\mathrm{~km}^{2}\right)$ over $55 \mathrm{yr}, A$ is the coefficient of $H$, and $C$ is a constant. I also express confidence limits (CL) of $A$ and $C$ by modifying the $\mathrm{CL}$ of odds ratios,

$\mathrm{CL}$ of $A=A \pm(\boldsymbol{\alpha} \times \mathrm{SE}), \mathrm{CL}$ of $C=C \pm(\boldsymbol{\alpha} \times \mathrm{SE})$, wherein $\boldsymbol{\alpha}$ is 1.04 for $70 \% \mathrm{CL}$ and 1.96 for $95 \% \mathrm{CL}$, and SE is the standard error of $A$ or $C$. I also calculated values of $P_{-}$taking $70 \% \mathrm{CL}$ and $95 \% \mathrm{CL}$ of $A$ and $C$. By assuming that population extinctions occur by demographic and environmental stochasticity following a Poisson process, one can calculate the probability of persistence for $100 \mathrm{yr}$ and $1000 \mathrm{yr}$ as $P_{-} 100 / 55$ and $P_{-} 1000 / 55$, respectively.

\section{RESULTS}

The logistic model $(A=0.0086, C=.0 .797)$ shows significant goodness of fit to the relationship between probability of survival $\left(P_{-}\right)$and habitat area $(H)(R 2=0.236$; likelihood ratio test, $X 2$ $=14.806, \mathrm{df}=1, p<.0001, n=50 ;$ Fig. 1$)$. The significant positive value of $A(X 2=4.883, p=.027)$ indicates that survival probability $\left(P_{-}\right)$increased with habitat area $(H)$.

Next, I calculated the probabilities of persistence for 100 and 1000 yr. For populations occupying 25 $\mathrm{km}^{2}$ and $250 \mathrm{~km}^{2}$ for $100 \mathrm{yr}$ the probabilities are $16 \%$ and $66 \%$, respectively. Habitat areas satisfying $95 \%$ probability of a population persisting for $100 \mathrm{yr}$ and $99 \%$ for $1000 \mathrm{yr}$ are 525 and $975 \mathrm{~km}^{2}$, respectively (the unit of area is $25 \mathrm{~km}^{2}$; Table I). However, the confidence limits of both $A$ and $C$ in the regression equation are large $(A: 70 \% \mathrm{CL}, .0046-.0127 ; 95 \% \mathrm{CL}, .0010-.0163 ; C: 70 \% \mathrm{CL}, .1 .419$ to $.0 .177 ; 95 \% \mathrm{CL}, .1 .973$ to .376). Assuming lower $70 \%$ and $95 \% \mathrm{CL}$ for $A$ and $C$, respectively, habitat areas satisfying each conservation target range from 975 to $1975 \mathrm{~km}^{2}$ and from 5600 to 9600 $\mathrm{km}^{2}$, respectively (Table I).

Table I. Habitat areas of local populations of Japanese macaques persisting for $100 \mathrm{yr}$ and $1000 \mathrm{yr}$ at $95 \%$ and $99 \%$ of probability

\begin{tabular}{|c|c|c|c|c|c|c|}
\hline \multirow{3}{*}{$\begin{array}{l}\text { Probability of } \\
\text { survival (\%) }\end{array}$} & \multicolumn{6}{|c|}{ Habitat area $\left(\mathrm{km}^{2}\right)$ persisting } \\
\hline & \multicolumn{3}{|c|}{ for $100 \mathrm{yr}$} & \multicolumn{3}{|c|}{ For $1000 \mathrm{yr}$} \\
\hline & $P^{a}$ & $P-70^{b}$ & $P-95^{C}$ & $P^{a}$ & $P-70^{b}$ & $P-95^{C}$ \\
\hline 95 & 525 & 975 & 5600 & 775 & 1600 & 7950 \\
\hline 99 & 700 & 1325 & 7275 & 975 & 1975 & 9600 \\
\hline
\end{tabular}

Note. The unit of habitat area was $25 \mathrm{~km}^{2}$.

$a$ Habitat area calculated from $P_{-}$corresponding to $95 \%$ and $99 \%$ of survival.

$b$ Habitat area calculated from lower $70 \%$ confidence limits of A and C corresponding to $95 \%$ and $99 \%$ of survival.

$c$ Habitat area calculated from lower $95 \%$ confidence limits of A and C corresponding to $95 \%$ and $99 \%$ of survival.

\section{DISCUSSION}

I examined 4 categories of conservation targets: $95 \%$ and $99 \%$ probability of persistence for $100 \mathrm{yr}$ and $1000 \mathrm{yr}$. I estimated the MAR for a population of Japanese macaques to be $525-975 \mathrm{~km}^{2}$ (Table I). 
However, one must pay attention to the large confidence limits of $A$ and $C$ in the logistic regression equation. Moreover, probabilities of extinction might be underestimates, because I could not take into account recolonizations during survey periods in the empirical data. In addition, because of probable lower reliability of information obtained in 1923, extinctions of populations undetected in 1923 might have occurred. Therefore, a much wider habitat area, of $\geqq 1000 \mathrm{~km}^{2}$, is required for actual conservation planning for local populations of Japanese macaques. The figures are based on data obtained in the periods when great destructions of habitat occurred, during which population extinction rates may have been higher than in other periods. However, habitat condition has not improved since 1978. Many areas of single-species conifer plantations, which decrease habitat quality for macaques (Hill et al., 1994), are likely to be maintained in the future.

The partial regression coefficient of the habitat area $(A)$ is significant, though the significance level is low $(p=.027)$. Japanese macaques inhabit various environments from warm temperate to cool temperate zones, and from coastal forests to subalpine areas. Key aspects of their ecology, such as population density, ranging pattern, feeding ecology, and social structure, may differ across their distribution with habitat type (Agetsuma and Nakagawa, 1998; Takasaki, 1981). Also, human activities - logging, plantation, farmland, pest control, protection policy - may vary with location. Analysis including natural environmental factors and human activities relevant to survival of macaque populations will improve the accuracy of MAR estimation. Further, the analysis will be effective for examining the probability of persistence in the future, even when some environmental changes occur as a result of human activities, management policies, and climatic changes. The approach should be useful to establish conservation plans for local populations of Japanese macaques.

The method of estimating MAR is much simpler and has fewer assumptions and estimates than others (Armbruster and Lande, 1993; Lande, 1987; Thiollay, 1989). One of the assumptions is that extinction occurs stochastically, and that it follows a Poisson process. Other researchers have commonly made a similar assumption in PVA (Lande, 1987; Sæther et al., 1998; Shaffer, 1981). Another assumption, which researchers also commonly use to estimate probabilities of occurrence of 2 categorical variables (Dixon, 1985; Dobson, 1990), is that the one can estimate probability of survival or extinction via logistic regression analysis. Moreover, this method requires only habitat area information and viability of populations during a certain period as variables, though detection of recolonizations to once extinct areas within the period may be difficult. Moreover, it is much easier to detect habitat area as a variable. Therefore, this method is widely applicable for comparisons with previous methods. Of course, understanding the long-term distributional changes of each wildlife species requires great effort. However, since the 1990s, researchers have collected distributional data for various species for use in Gap Analysis, which is a good conservation tool for wider scale approaches to species and biodiversity (Allen et al., 2001; Joly and Mayers, 2001; Scott et al., 1993). Some organizations have gathered information systematically (Joly and Mayers, 2001), which may provide the data required to estimate MAR for other species via a method similar to that presented here.

I focused on the viability of individual local populations, which are somewhat isolated. Even if some occasional genetic exchanges occur via long-distance immigrations by male Japanese macaques, their movements alone would not allow recolonization after local extinction of isolated populations. However, researchers observed extension of distribution through the expansion of habitat areas of local populations between 1923 and 1978 (Koganezawa, 1995). As a result, some local populations fused with one another and formed larger populations, in which case one can treat each local population as part of a larger metapopulation. For conservation of the whole population of Japanese macaques, one should also consider such habitat expansions, recolonizations, and fusion of local populations. 


\section{ACKNOWLEDGMENTS}

I thank Dr. G. Takimoto of the Field Science Center for Northern Biosphere, Hokkaido University for his advice on data analysis, and Dr. D. A. Hill of the School of Life Sciences, University of Sussex and 3 anonymous referees for their helpful comments on the manuscript. The research project Evaluation of Sustainable Forest Use Options and Their Perspectives of The Research Institute for Humanity and Nature supported part of the study.

\section{REFERENCES}

Agetsuma, N. (1995). Methods of vegetation rehabilitation for wildlife conservation. Primate Res. 11: 133-146 (in Japanese with English summary).

Agetsuma, N. (1998). Crop damage by wild Japanese macaques on Yakushima Island, Japan. Jpn. J. Conserv. Ecol. 3 : 43-55 (in Japanese with English abstract).

Agetsuma, N. (1999a). Present situation of Japanese wildlife reviewed from economic backgrounds: Introduction for young students. J. Econ. Dept. Akita U. Econ. Law 30: 11-23.

Agetsuma, N. (1999b). Roles of Primatology for wildlife management. In Nishida, T., and Uehara, S. (eds.), An Introduction to Field Primatology. Sekaishiso-Sha, Tokyo, pp. 300-326 (in Japanese).

Agetsuma, N., and Nakagawa, N. (1998). Effects of habitat differences on activity budget in Japanese monkeys: Comparison between Yakushima and Kinkazan. Primates 39: 275-289.

Allen, C. R., Perlstine, L. G., and Kitchens, W. M. (2001). Modelling viable mammal populations in gap analyses. Biol. Conserv. 99: 135-144.

Amagasa, T., and Ito, T. (1978). Taishojidai no nihinzaruno bunpu. Nihonzaru 4: 96-106 (in Japanese).

Armbruster, P., and Lande, R. (1993). A population viability analysis for African elephant (Loxodonta africana): How big should reserves be? Conserv. Biol. 7: 602-610.

Berger, J. (1990). Persistence of different-sized populations: An empirical assessment of rapid extinctions in bighorn sheep. Conserv. Biol. 4: 91-98.

Dixon, W. J., ed. (1985). BMDP Statistical Software Manual. University of California Press, Berkeley, CA.

Dobson, A. J. (1990). An Introduction to Generalized Linear Models. Chapman and Hall, London.

Hill, D. A., Agetsuma, N., and Suzuki, S. (1994). Preliminary survey of group density of Macaca fuscata yakui in relation to logging history at seven sites in Yakushima Japan. Primate Res. 10: 85-93.

Honyurui Bunpu Chousa Kaken Group. (1979). Kamoshika, sika, higuma, tsukinowaguma, nihonzaru, inosisi no zenkoku bunnu narabini higai bunpu. Biol. Sci. (Tokyo) 31: 96-112 (in Japanese).

IUCN. (2001). IUCN red list categories and criteria: version 3.1. IUCN Species Survival Commission. IUCN, Gland, Switzerland and Cambridge, UK.

Iwano, T. (1974). Distribution of Japanese monkeys. Nihonzaru 1: 5-62 (in Japanese with English summary).

Joly, K., and Mayers, W. L. 2001. Pattern of mammalian species richness and habitat associations in Pennsylvania. Biol. Conserv. 99: 253-360.

Kawamoto, Y. (2002). Nihonzaru no seiritu ni kannsuru shudanidengaku teki kenkyu. Asian Paleoprimatol. 2: 55-73 (in Japanese).

Kinnaird, M. F., and O'Brien, T. G. (1991). Viable populations for an endangered forest primates, the Tana River Crested Mangabey (Cercocebus galeritus galeritus). Conserv. Biol. 5: 203-213.

Koganezawa, M. (1995). Extraction and isolated degree of the local population of Japanese monkeys using geographic information system. Primate Res. 11: 59-66 (in Japanese with English summary).

Lande, R. (1987). Extinction thresholds in demographic models of territorial populations. Am. Nat. 130: 624-635.

Maruhashi, T. (1982). An ecological study of troop fissions of Japanese monkeys (Macaca fuscata yakui) on Yakushima Island, Japan. Primates 23: 317-337.

McKelvey, K., Noon, B. R., and Lamberson, R. H. (1993). Conservation planning for species occupying fragmented landscapes: The case of the northern spotted owl. In Kareiva, P. M., Kingsolver, J. G., and Huey, R. B. (eds.): Biotic Interactions and Global Change. Sinauer Associates, Sunderland, MA, pp. 424-450.

Muroyama, Y., Imae, H., and Okuda, K. (2000). Radio tracking of a male Japanese macaque emigrated from its group. Primates 41: 351-356.

Oi, T., Mori, O., Ashizawa, S., Matuoka, S., Agetsuma, N., Nakamura, T., Endo, J., Iwatuki, K., Otuki, K., and Izawa, K. (1997). The distribution and conservational status of wild Japanese macaques (Macaca fuscata fuscata) in Tohoku district, Japan. Wildl. Forum 3: 5-21 (in Japanese).

Primack, R. B. (1995). A Primer of Conservation Biology. Sinauer Associates, Sunderland, MA. 
Reid,W. V., andMiller, K. R. (1989). Keeping Options Alive: The Scientific Basis for Conserving Biodiversity. World Resources Institute, Washington, DC.

Sæther, B., Engen, S., Swenson, J. E., Bakke, Ø., and Sandegren, F. (1998). Assessing the viability of Scandinavian brown bear, Ursus arctos, populations: The effects of uncertain parameter estimates. Oikos 83: 403-416.

SAS Institute (1998). Stat View. Second edition. Japanese version. Hulinks, Tokyo, Japan.

Scott, J. M., Davis, F., Csuti, B., Noss, R., Butterfield, B., Groves, C., Anderson, H., Caicco, S., D’Erchia, F., Edwards Jr, T. C., Ulliman, J., and Wright, R. G. (1993). Gap Analysis: A geographic approach to protection of biological diversity. Wildl. Monogr. 123: 1-41.

Shaffer, M. L. (1981). Minimum population sizes for species conservation. Bioscience 31: 131-134.

Sugiura, H., Agetsuma, N., and Suzuki, S. (2002). Troop extinction and female fusion in wild Japanese macaques in Yakushima. Int. J. Primatol. 23: 69-84.

Takasaki, H. (1981). Troop size, habitat quality and home range area in Japanese macaques. Behav. Ecol. Sociobiol. 9: 277-281.

The Southern Kanto Organization for the Study and Information of Japanese Macaques. (1995). Status report on the local populating of Japanese macaques in the southern Kanto district (1994). Primate Res. 11: 147-158 (in Japanese with English summary).

Thiollay, J. M. (1989). Area requirement for the conservation of rain forests and game birds in French Guiana. Conserv. Biol. 3: 128-137.

Uehara, S., and Koganezawa, M. (1976). Nihonzaru no bunpu no rekisiteki hensen. Sci. J. Kagaku 46: 737-744 (in Japanese).

Wissel, C., and Zaschke, S. (1994). Stochastic birth and death processes describing minimum viable populations. Ecol. Model. 75/76: 193-201. 